УДК 551.89(571.1)

ДИСКУССИОННЫЕ ПРОБЛЕМЫ ПАЛЕОГЕОГРАФИИ ПЛЕЙСТОЦЕНА ЛЕДНИКОВЫХ ОБЛАСТЕЙ ЗАПАДНОЙ СИБИРИ

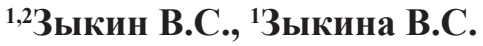 \\ ${ }^{1}$ ФББУН «Институт геологии и минералогии СО РАН им В.С. Соболева», Новосибирск, \\ e-mail: zykin@igm.nsc.ru; \\ ${ }^{2}$ ФАОУ ВО «Новосибирский национальньий исследовательский государственньй университет», \\ Новосибирск
}

\begin{abstract}
В статье обсуждаются основные дискуссионные проблемы палеогеографии плейстоцена ледниковых областей Западной Сибири. На основании данных о строении, литологической характеристике и геоморфологическом положении четвертичных отложений, полученных в последнее время на севере Западно-Сибирской равнины и в Горном Алтае, значительно уточнено распространение, количество, масштабы, границы и возраст оледенений в плейстоцене этого обширного региона. Наличие ледогранников в башкаусской свите Горного Алтая, отнесенной по палеомагнитной и палеонтологической характеристике к хрону Матуяма свидетельствует, что в горных областях юга Сибири в раннем плейстоцене существовало оледенение, превосходившее современное. Обнаружение в ледниковой зоне севера Западной Сибири, на поверхности второй террасы р. Надым в Надымском Приобье криогенных полигонов с первично-песчаными клиньями не соответствует присутствию на этой территории покровного оледенения во время последнего ледникового максимума. Их формирование происходило в перигляциальных условиях, при среднегодовых температурах до $-12--20^{\circ} \mathrm{C}$, и среднегодовой сумме осадков менее 100 мм. Показано, что оледенение Горного Алтая в последний ледниковый максимум носило горно-долинный характер. Выходившие из долин боковых притоков в магистральную долину относительно небольшие ледники, морены которых прослежены вдоль Чуи и Катуни от устья Айгулака до пос. Майма, продвигались по ней на незначительное расстояние, не сливаясь в единый ледник. Исследование четвертичных отложений в долинах рек Чуя и Катунь Горного Алтая не выявило в них следов гляциально обусловленных катастрофических суперпаводков. На этом участке долины рек Чуя и Катунь в плейстоцене были выполнены речными, озерными, ледниковыми, флювиогляциальными и склоновыми отложениями.
\end{abstract}

Ключевые слова: Западная Сибирь, плейстоцен, палеогеография, ледниковые области, ледниковые отложения

\title{
DISCUSSION PROBLEMS OF PLEISTOCENE PALEOGEOGRAPHY OF GLACIAL REGIONS OF WESTERN SIBERIA
}

\author{
1,2Zykin V.S., ${ }^{1}$ Zykina V.S.
}

${ }^{1}$ V.S. Sobolev Institute of Geology and Mineralogy SB of the RAS, Novosibirsk, e-mail: zykin@igm.nsc.ru; ${ }^{2}$ National Research Novosibirsk State University, Novosibirsk

\begin{abstract}
The paper deals with main discussion problems of Pleistocene Paleogeography of glacial regions of Western Siberia. Using the data on the structure, lithological characteristics, geomorphological sutuations of Quaternary deposits obtained in last time on the north of West Siberian Plain and in Altai Mountains the Pleistocene glaciation spreadings, quantity, scales, boundaries and ages in this vast region were defined more exactly. The availability of a glacial faceted boulders buried in the Bashkaus Formation in Gornyi Altai attributed to Matuyama Chron testifies that the glaciation existed in Early Pleistocene in the Mountain regions of Southern Siberia. The detection of cryogenic poligonal structures with primery sand wedges on the surface of the second terrace of the Nadym River in glacial zone of West Siberia is inconsistent with the existence of ice sheets in the area during Last Glacial Maximum. The formation of this cryogenic structures occurred in periglacial conditions in a very cold climate when temperature dropped to -12 to $-20^{\circ} \mathrm{C}$, wereasthe total annual precipitation fell below $100 \mathrm{~mm}$. In Altai Mountains Glaciation in Last Glacial Maximum was moutain-valley glaciation. The small glaciers from the valleys of tributaries reached the valleys of Katun and Chuya rivers and advanced on the small distances, but were not merged into one glacier. The investigations of Quaternary deposits in the valleys of Katun and Chuya rivers of Altai Mountains have not revealed manifestations of cataclysmic glacial superfloods. The valleys of Katun and Chuya rivers in Pleistocene were filled river, lake, glacial, slope, and fluvioglacial deposits.
\end{abstract}

Keywords: Western Siberia, Pleistocene, Paleogeography, glacial regions, glacial deposits

Изучение четвертичных отложений Западной Сибири имеет длительную историю. Особое внимание уделялось исследованию важнейших событий плейстоцена - материковых оледенений. По мере накопления фактического материала постепенно детализировалась стратиграфическая последовательность четвертичных отложений, разрабатывались критерии и методы диагностики генетических типов осадков, воз- растала обеспеченность данными абсолютного датирования, появлялись новые данные о геологическом строении конкретных разрезов, уточнялось количество, распространение, масштаб и возраст оледенений. В связи с появлением все более детальных геологических данных трансформировались палеогеографические реконструкции и концепции развития этой огромной территории, уточнялось влияние различных 
природных процессов на формирование природной среды и климата в различные эпохи четвертичного периода. Появление новых геологических материалов приводит как к уточнению имеющихся палеогеографических концепций, так и к значительным противоречиям в палеогеографической интерпретации новых фактических данных и многочисленным дискуссиям. Особенную важность приобретает достоверность стратиграфической и палеогеографической информации для установления закономерностей изменений природной среды и климата, которые могут быть применены для прогноза их изменений в ближайшем будущем. Часто существование различных палеогеографических реконструкций в одних и тех же районах зависит от детальности и комплексности исследований, сложности геологического строения территории, недостаточности разработки критериев диагностики генезиса отложений, от степени проработки фактического материала, а также профессионализма исследователей. Целью статьи является обсуждение основных дискуссионных проблем, связанных с развитием оледенений в плейстоцене Западной Сибири, а также особенностями проявления сопутствующих им событий на основании новых материалов, полученных авторами при комплексном изучении строения, состава и геоморфологического положения разрезов четвертичных отложений в ледниковых областях. В ней обобщены исследования, проведенные литолого-генетическим, палеопедологическим, геоморфологическим, радиоуглеродным и палеомагнитным методами. Среди многочисленных проблем палеогеографии четвертичного периода ледниковых областей Западной Сибири кратко рассмотрены только те проблемы, в решении которых авторам в последнее время в результате комплексных детальных исследований удалось получить новые материалы, позволившие уточнить прежние палеогеографические представления.

\section{Первое материковое оледенение в Западной Сибири}

Проблема времени возникновения первого материкового оледенения в конкретных районах Евразии является определяющей для стратиграфии и палеогеографии четвертичного периода. В связи со значительной денудацией в ледниковых областях следы древних оледенений сохранились фрагментарно. На ранних этапах исследования четвертичных отложений Западной
Сибири к наиболее ранним ледниковым образованиям Е.Н. Щукиной в 1960 г. была отнесена эоплейстоценовая башкаусская свита высокогорий Алтая, включающая бурые валунно-галечные суглинки и супеси с выветрелыми валунами. Несколько позже Е.В. Девяткин, Н.А. Ефимцев и И.Г. Лискун на основании литолого-стратиграфических исследований пришли к мнению о неледниковом происхождении башкаусской свиты, ограничив условия ее формирования преимущественно аллювиальным и частично пролювиальным генезисом. Недавно на основании наличия в некоторых разрезах башкаусской свита валунов, частичной выветрелости обломочного материала, его слабой сортировке, присутствия неокатанного материала, отсутствию слоистости П.А. Окишев [1] отнес эти отложения к ледниковым образованиям.

Изучение разрезов башкаусской свиты в опорных разрезах по периферии Чуйской впадины Алтая дало возможность установить в ней неопровержимые доказательства развития оледенения во время ее формирования в виде ледогранников [2]. В башкаусской свите они встречены в двух разрезах в противоположных частях впадины. У подножия южного склона Курайского хребта в долине р. Туерык ледогранники до $20 \mathrm{~cm}$ в поперечнике с хорошо пришлифованными гранями приурочены к нижней части свиты, где неравномерно рассеяны в линзах мощностью до 3 м серовато-желтого, плохо сортированного алеврита с большим количеством песка, гравия, различно окатанной гальки, мелких валунов [2]. Галька и валуны различно окатаны, преимущественно плохо, встречаются щебень и отломы разного размера. Размер обломков не превышает 30 см в поперечнике. Обломки пород несут следы поверхностного выветривания.

В ставшем уже классическим чаганском разрезе в левом борту долины р. Чаган, расположенном у северного подножия Южно-Чуйского хребта, башкаусская свита распространена в юго-западной части обнажения на протяжении 600 м. Ледогранники были обнаружены в средней и верхней (рис. 1) части свиты. В этом разрезе башкаусская свита мощностью 37 м сложена уплотненным, различно окатанным, плохо сортированным галечником серовато-желтого цвета, в средней части свиты коричневато-серым. Встречаются мелкие валуны до 0,3 м. Много неокатанных обломков от щебня до мелких отломов. Присутствуют ледогранники, на некоторых из них имеет- 
ся ледниковая штриховка, иногда они образуют небольшие скопления. Характерной особенностью свиты в разрезе является наличие большого количества выветрелых и растрескавшихся галек и валунов, щебня и отломов, которые, как правило, часто встречаются в морене. Заполнителем служит желтовато-серый, плотный, глинистый, песчанистый, слюдистый алеврит. Литологические особенности башкаусской свиты разреза позволяют относить эти отложения к водно-ледниковым образованиям.

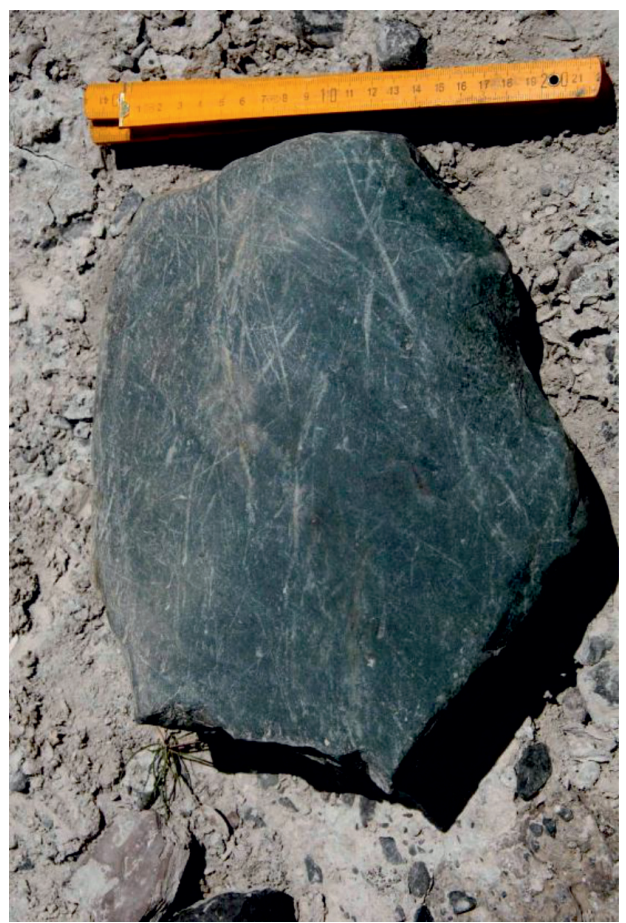

Рис. 1. Ледогранник с ледниковой штриховкой из верхней части нижнеплейстоиеновой башкаусской свиты Горного Алтая в обрыве правого склона долины р. Чаган

Проведенные палеомагнитные исследования башкаусской свиты по р. Туерык [2] и в чаганском разрезе [3] позволили сопоставить их магнитостратиграфические разрезы и позволили получить ее магнитостратиграфический разрез, состоящий из достаточно продолжительной магнитозоны обратной полярности и окаймляющих ее относительно маломощных магнитозон прямой полярности. Сопоставление этого магнитостратиграфического разреза с магнитохронологической шкалой [4] с учетом стратиграфического расположения башкаусской свиты в стратиграфической схеме кайнозоя Горного Алтая позволяет отнести прямо намагниченную магнитозону в ниж- ней части свиты к верхней части хрона C2An [4] или хрона Гаусс [5], а мощную магнитозону обратной намагниченности в средней части свиты к хрону C2r [4] или нижней части хрона Матуяма [5]. Магнитозона прямой полярности в верхней части свиты в этом случае весьма вероятно будет относиться к субхрону C2n [4] или субхрону Олдувей [5]. Граница между палеомагнитными эпохами Гаусс - Матуяма [5] или хронами C2An.1n и C2r [4] проходит на геохронологическом уровне 2,58 млн лет $[4,5]$. Таким образом, палеомагнитные материалы не противоречат отнесению следов наиболее раннего оледенения Горного Алтая к началу плейстоцена близ хронологического рубежа 2,58 млн лет.

\section{Последнее оледенение Западной Сибири}

Данные о масштабах проявления и положении границ последнего оледенения (сартанского), как на территории севера Западной Сибири, так и в горах Южной Сибири до сих пор остро дискуссионны. По данным многих исследователей ледниковые образования последнего оледенения на севере Сибири были распространены на небольшой площади. На примыкающих с севера к Западно-Сибирской равнине горных сооружениях на высотах 800-900 м последнее оледенение имело горно-долинный характер [6]. Тем не менее среди специалистов существует мнение, что ледниковые образования последнего оледенения широко представлены в районе Сибирских увалов и протягиваются до $61^{\circ}$ с.ш.

При изучении четвертичных образований ледниковой зоны севера Западной Сибири, на поверхности второй террасы р. Надым в Надымском Приобье были установлены мерзлотные полигоны с первично-песчаными клиньями [7]. Их присутствие не соответствует наличию на этой территории покровного оледенения во вторую половину позднего плейстоцена. Образование подобных криогенных структур возможно только в очень холодных перигляциальных условиях, холоднее современных на $13-21^{\circ} \mathrm{C}$, при среднегодовых температурах до $-12--20^{\circ} \mathrm{C}$ и при незначительной среднегодовой сумме осадков менее 100 мм. Таким образом, полученные данные ограничивают развитие последнего оледенения на севере Западно-Сибирской равнины как максимум $65^{\circ}$ с.ш.

Достаточно противоречивы взгляды различных исследователей на распространение последнего оледенения на Горном 
Алтае. Большинство геологов и палеогеографов рассматривают наличие крупных валунов и глыб до 10 м в поперечнике и их скоплений в отложениях террас долин рек Катуни, Чуи и Бии следами обширных оледенений. С 1980 гг. некоторые как российские [8-10], так и зарубежные исследователи [11-13] особенности рельефа и строения рыхлых толщ долин рек Чуя и Катунь, в том числе присутствие в них глыбового материала, объясняют проявлением внезапных суперпаводков, образующихся в результате спуска гигантских озер, подпруженных ледниками в высокогорьях Алтая.

Одним из районов Горного Алтая, где на основании присутствия в рыхлых отложениях террас долины р. Катуни «мощных валунногалечников с прослоями глыбовников и отдельными глыбами» [9] выделена «типичная ассоциация гигантских гляциальных паводков» [9], является участок в правом борту долины близ пос. Майма. Изучение геоморфологического строения этой территории и состава аллювия террас долины Катуни в этом районе показало, что крупные валуны и глыбы до 7 м в поперечнике неравномерно расположены в хорошо окатанных речных галечниках 2, 3, и 4-й террас и на их поверхности в виде инородного материала. Они не несут следов окатывания или других способов обработки в водном потоке, имеют острые ребра и углы, выветрелые или с поверхности или до состояния сапролита (разрушаются при незначительном ударе) и представлены исключительно легко узнаваемыми гранитоидами со шлирами рыбалкинского (айского) массива, распространенного на правобережье Катуни в районе пос. Майма. Эти гранитоиды обнажаются, в том числе в сильно выветрелом состоянии, в небольших речных долинах и логах, впадающих в Катунь справа. В аллювии 2-й террасы здесь обнаружены ледогранники с ледниковой штриховкой. Единственным возможным путем перемещения сильно выветрелых глыб без их разрушения могла быть только их транспортировка ледниками, способными переносить глыбы и другие обломки горных пород на поверхности льда или внутри него, не меняя их формы. Отсутствие крупных скоплений глыб, не образующих моренных комплексов, свидетельствует о незначительных размерах ледников, выходящих из боковых притоков в долину магистральной реки, не перегораживая ее. Глыбы незначительно перераспределялись при формировании флювиогляциальных отложений, когда сток в долине Катуни увеличивался.
Крупнейшее нагромождение эрратических глыб, образующих морену, идентифицируется в Яломано-Катунской зоне, в среднем течении долины Катуни, на ее левом берегу, на площадке террасы высотой 65 м, вблизи ее причленения к 180-й террасе [14]. Это так называемый «сад камней». Выступающее над поверхностью террасы на 3-4 м нагромождение глыб локализуется вдоль тылового шва террасы от устья р. Иня почти на 2 км и здесь, по-видимому, служит ее цоколем. Вверх по течению от устьевого участка р. Ини глыбы на площадке этой террасы отсутствуют. Материал большинства глыб прдставлен гранодиоритом и палеозойскими метаморфическими сланцами. Размеры глыб обычно не превышают 6 м в поперечнике, но некоторые из них достигают 12 м. Одиночные глыбы встречаются на склоне уступа 180-м террасы и на ее площадке вблизи бровки, отсутствуя в теле самой террасы. По представлениям А.Н. Рудого с соавторами [15] это нагромождение глыб сформировалось в результате их концентрации катастрофическим суперпаводком. Критериями отнесения этого скопления глыб к морене послужили следующие признаки:

1. Крупные размеры глыб, их неокатанность, наличие на них острых ребер и углов.

2. Материал, слагающий глыбы, представлен породами, обнажающимися только в долине р. Иня.

3. Присутствие на некоторых глыбах одной, реже двух плоскостей пришлифовки движущимся льдом.

4. Отсутствие ориентировки и сортировки глыб.

5. Многие глыбы гранодиоритов разделены трещинами на более мелкие отдельные глыбы, лежащие на месте без перемещения.

6. Раздробленность глыб палеозойских метаморфических сланцев открытыми призматическими трещинами кливажа, которые образуются только при коренном залегании горных пород и не могут сформироваться в отдельной глыбе, в случае их перемыва подобные глыбы разрушаются.

Так в разрезе 65-м террасы в левом борту долины Катуни, напротив «сада камней» с двумя мощными слоями перемытого глыбовника из этой морены отсутствуют глыбы с кливажными трещинами. Единственным возможным путем перемещения раздробленных глыб без их разрушения могла быть только их транспортировка ледником, способным переносить глыбы и другие обломки горных пород на поверхности льда или внутри него, не меняя их формы. 


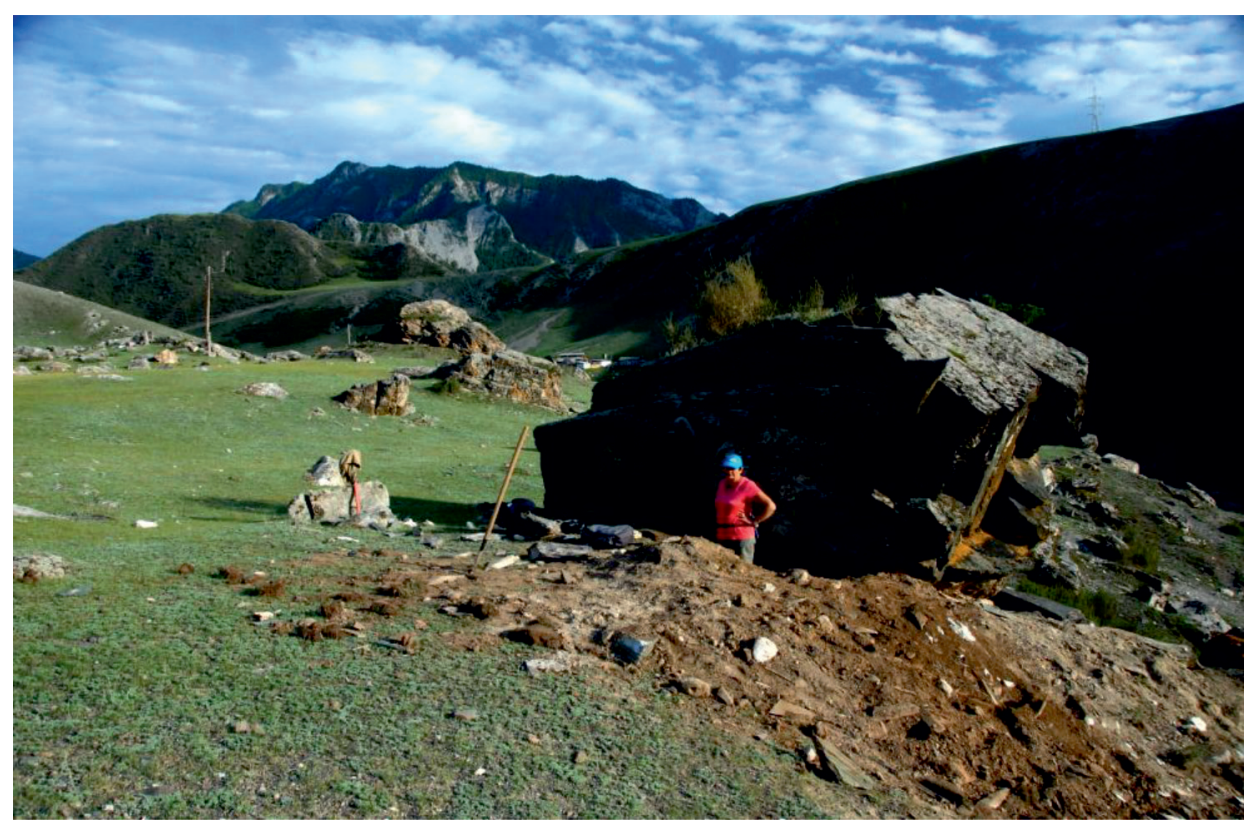

Рис. 2. Следь отступания ледника последнего оледенения в долине р. Иня, 1,5 км от устья в виде неокатанных гльб палеозойских сланцев с кливажом

Следы отступания ледника, сформировавшего описанную морену, хорошо сохранились в долине р. Иня в виде отдельных глыб, на ее склонах и площадке ее террасы (рис. 2), сочленяющейся с террасой Катуни высотой 65 м. Часть глыб погружена в маломощные, плохо сортированные галечники, слагающие эту террасу Ини. Возраст глыбового формирования глыбового нагромождения на террасе высотой 65 м установлен А.Н. Рудым с соавторами [15] по 4 датировкам по космогенным изотопам ${ }^{10} \mathrm{Be}$ глыб гранодиоритов, среднее значение которых соответствует $15532 \pm 915$ лет назад. Приведенные данные позволяют считать, что нагромождение глыб на площадке террасы высотой 65 м и глыбы в долине р. Иня являются образованиями позднеплейстоценового (сартанского) оледенения Западной Сибири. Выходящий из долины Ини ледник, судя по расположению глыбового материала на противоположном левом борту долины р. Катунь, подпирал уступ высокой террасы, полностью заполняя долину Катуни и продвигаясь по ней на незначительное расстояние. В это время сток в долине Катуни мог отсутствовать или быть значительно слабее современного, так как водный поток, близкий стоку современной реки, должен был эродировать относительно небольшой ледник и не дать ему достичь другого борта долины.
Достаточно мощная морена, отмеченная еще В.А. Обручевым в 1914 г., залегает в приустьевой части долины р. Айгулак, являющейся правым притоком р. Чуи. Она сложена типичным диамиктоном с большим количеством щебня, алеврита, крупных и мелких обломков горных пород до 3 м в поперечнике и валунов. На некоторых из валунов с пришлифованной поверхностью присутствует ледниковая штриховка. Редко встречаются ледогранники и раздавленные глыбы палеозойских сланцев с нахождением обломков на месте дробления. Торцовая часть морены, выходящая в долину р. Чуя переработана флювиальными процессами.

Таким образом, во время последнего ледникового максимума в горных районах Алтая небольшие ледники, формировавшиеся в долинах боковых притоков долин Чуи и Катуни, незначительно выходили в магистральные долины и не образовывали значительных моренных комплексов. Прерывистое распространение морен в этих долинах и приуроченность их к устьям боковых притоков не свидетельствует об образовании движущегося по долине Катуни крупного ледника, выходящего за пределы горной территории. Между многочисленными ледниками в долинах рек Чуя и Катунь, а также в долине р. Иня формировались озера, отмеченные в разрезах маломощными неравномерно слоистыми алевритами или па- 
раллельно слоистыми дресвяниками низов ининской толщи. Оледенение в горных областях Западной Сибири носило горно-долинный характер и занимало незначительные площади.

\section{Сток в долинах Горного Алтая в ледниковое время}

Среди природных процессов, тесно связанных с оледенениями в Горном Алтае, особую роль играет сток в речных долинах во время их развития. С 1980 гг. некоторые исследователи (В.В. Бутвиловский, Е.В. Деев, И.Д. Зольников, Д.В. Назаров, С.В. Парначев, А.Н. Рудой, Г.Г. Русанов, P.A. Carling, J. Herget, A.U. Reuther) предполагают, что многие особенности геологического строения рыхлых четвертичных отложений и рельефа в долинах р. Чуя и Катунь в плейстоцене следует связывать с прохождением по этим долинам катастрофических суперпаводков, вызванных внезапными спусками огромных ледниково-подпрудных озер в высокогорьях Алтая. Другие исследователи Горного Алтая (Б.М. Богачкин, Б.А. Борисов, Е.В. Девяткин, Н.А. Ефимцев, В.С. Зыкин, В.С. Зыкина, Л.Н. Ивановский, А.А. Мистрюков, П.А. Окишев, А.В. Поздняков, А.А. Свиточ, Д.А. Тимофеев и др.) считают, что долины этих рек заполнены речными, ледниковыми, склоновыми и флювиогляциальными образованиями. Рассмотрим основные диагностические признаки, приводимые сторонниками гигантских катастрофических паводков для доказательства своих взглядов. Анализ этих данных стал возможен на основании новых материалов, полученных в результате детальных комплексных исследований на основных опорных разрезах в Яломано-Катунской зоне в долинах Чуя и Катунь, а также в долине Чуи от пос. Кош-Агач до устья, проведенных в 1995-2016 гг.

К основным критериям отнесения четвертичных отложений, выполняющих долины Чуи и Катуни, к образованиям гигантских катастрофических паводков относится наличие в них элементов паводкового циклита, выделенного С.В. Парначевым в 1999 г. [10]. Наиболее характерными элементами этого циклита являются селевая и пойменная фации. За опорный разрез паводкового циклита принят разрез нижней пачки ининской толщи в уступе 180-метровой террасы, находящийся в 500 м ниже устья р. Иня, в правом борту долины Катунь. В основании паводкового циклита [10] был описан валунно-глыбовый горизонт мощно- стью до 8 м с наибольшим размером обломков до 4 м, отнесенный к селевой фации. Исследование этого разреза показало, что при описании паводкового циклита С.В. Парначевым [10] за его базальный валунноглыбовый горизонт был ошибочно принят базальный горизонт 65-метровой террасы, причленяющийся в данном разрезе к уступу 180-метровой террасы. При изучении этого разреза установлено, что в основании ининской толщи и опорного разреза «паводкового циклита» залегает плохо сортированный, хорошо окатанный галечник мощностью 2,8 м, с неотчетливой линзовидной слойчатостью, с большим количеством плохо сортированного гравия, дресвы и разнозернистого песка. Встречается щебень и хорошо окатанные валуны до 30 см в поперечнике. Редко присутствуют обломки коренных пород до 50 см в поперечнике. Плоская галька очень слабо наклонена вдоль современного течения реки. Строение и мощность этого слоя обычны для базального горизонта аллювия горной реки. Следует отметить, что описанный выше разрез является единственным в Яломано-Катунской зоне, где вскрываются базальные слои ининской толщи. В разрезе в обрыве 220-м террасы Катуни ниже пос. Инегень ининская свита залегает на хорошо промытых речных отложениях без базального горизонта и представлена в нижней части параллельно слоистыми дресвяниками. Несколько выше по Катуни в разрезе высокой 100-м террасы у устья руч. Сок-Ярык галечники, относимые к ининской толще [10], расположены на мощной (65 м), хорошо выраженной морене, описанной Б.М. Богачкиным в 1981 г. и залегающей у уреза воды в реке на погребенном среднеплейстоценовом аллювии. Один из ключевых участков наиболее крупного скопления глыб в более молодых образованиях сальджарской толщи выходит на поверхность 65-м террасы на левобережье Катуни, несколько ниже устья р. Иня и, как показано выше, принадлежит морене последнего сартанского оледенения. Следовательно, во всех известных ныне разрезах, в отложениях, относимых к образованиям гигантских катастрофических паводков, отсутствует характерный базальный элемент паводкового циклита.

Следующим характерным элементом паводкового циклита является так называемая пойменная фация, сложенная параллельно-слоистыми «дресвяниками и щебнедресвяниками», переносимыми, по мнению некоторых сторонников гляциальных па- 
водков, во взвешенном состоянии и выпадающими из движущейся толщи воды при резком падении скорости и несущей способности потока в эрозионной тени. Наличие слоев параллельно-слоистых «дресвяников и щебнедресвяников», состоящих из мелких остроугольных обломков палеозойских сланцев различных размеров, в рыхлых толщах долин рек Чуя и Катунь, объявлено И.Д. Зольниковым [8, 16] «визитной карточкой суперпаводков». Следует отметить, что слои дресвяников, в которых преобладают неокатанные обломки палеозойских сланцев, довольно часто встречаются во всех четвертичных толщах различного возраста и генезиса, выполняющих долины Катуни и Чуи, так как борта и днища их долин часто сложены палеозойскими сланцами. Иногда они залегают в основании ининской свиты на более древних толщах без базального горизонта. Эти дресвяники состоят из чередования субпараллельных протяженных плоских слойков, имеющих толщину от 5 до $20 \mathrm{~cm}$, нижний из слойков состоит из более мелкозернистого осадка (с различным содержанием песка, гравия или дресвы), верхний слоек сложен более крупнозернистыми дресвой и песком. Часто их слойчатость наклонена к осевой части долины под углом 20-30. В каждой из нижних пачек ининской свиты происходит отчетливое увеличение размеров обломков снизу вверх по разрезу. В параллельно-слоистых дресвяниках также снизу вверх по разрезу постепенно увеличивается толщина слойков и размер обломков в слойках. Подобная закономерность в осадконакоплении характерна для озерных осадков [17].

Наиболее полную информацию о генезисе нижней части ининской свиты дает разрез 180 м террасы в правом борту долины р. Катунь, в обрыве левого склона долины р. Иня, расположенный в $500 \mathrm{M}$ выше ее устья, непосредственно ниже автомобильного моста через реку. Здесь р. Иня поперек сечет высокую террасу р. Катунь, вскрывая нижнюю часть ининской свиты. Разрез сложен темно-серыми, параллельно-слоистыми дресвяниками, в которых вверх по разрезу постепенно увеличивается мощность каждой пары слойков и размер обломков в них. В толще дресвяников разреза на 6 уровнях находятся линзы преимущественно хорошо и умеренно окатанных галечников с неравномерной линзовидной слойчатостью и слойчатостью выполнения, имеющих резкую нижнюю границу и выполняющих руслообразные врезы до 8 м шириной. По текстурным особенностям и руслообразной форме линз галечника, их размерам они относятся к отложениям небольшой горной реки, которую наследует современная р. Иня. Соотношение с вмещающими линзы галечника породами свидетельствует, что реконструируемая речка впадала в бассейн, в котором накапливались параллельно-слоистые дресвяники. Хорошая сохранность русловых отложений показывает, что это был достаточно крупный озерный бассейн. При попадании отложений небольшой реки в быстро движущийся поток катастрофического суперпаводка они не смогли бы остаться в разрезе. Следовательно, нижняя часть ининской свиты, включающая параллельно-слоистые дресвяники, формировалась в озерном бассейне.

\section{Заключение}

Проведенные исследования строения, состава, геоморфологического положения четвертичных отложений в ледниковых областях Западной Сибири позволили значительно уточнить распространение, количество и масштабы оледенений в плейстоцене этого обширного региона. Присутствие ледогранников в башкаусской свите Горного Алтая, имеющей палеомагнитную характеристику, соответствующую хрону Матуяма, свидетельствует, что в горных областях юга Сибири в раннем плейстоцене существовало оледенение, превосходившее современное. Обнаружение на севере Западной Сибири, в ледниковой зоне на поверхности второй террасы р. Надым в Надымском Приобье мерзлотных полигонов с первично-песчаными клиньями не соответствует присутствию на этой территории покровного оледенения во вторую половину позднего плейстоцена. Показано, что последнее оледенение Горного Алтая носило горно-долинный характер. В последний ледниковый максимум в горных районах Алтая небольшие ледники, формировавшиеся в долинах боковых притоков долин Чуи и Катуни, незначительно выходили в магистральные долины и не образовывали значительных моренных комплексов. Исследование плейстоценовых отложений в долинах р. Чуя и Катунь Горного Алтая не выявило в них следов гляциально обусловленных катастрофических суперпаводков.

Работа выполнена в рамках государственного задания по проекту № 03302016-0017 и при финансовой поддержке Российского фонда фундаментальных исследований (грант № 16-05-00371). 


\section{Список литературы}

1. Окишев П.А. Рельеф и оледенение Русского Алтая / П.А. Окишев. - Томск: Изд-во Томского ун-та, 2011. - 382 с.

2. Зыкин В.С. Новые данные о наиболее древнем четвертичном оледенении на Горном Алтае / В.С. Зыкин, В.С. Зыкина, Л.Г. Смолянинова // Докл. РАН. - 2016. T. 466, № 3. - С. 315-318. DOI: 10.7868/S0869565216030245.

3. Разрез новейших отложений Алтая (стратиграфия и палеонтология Приобского плато, Подгорной равнины и Горного Алтая) / А.А. Свиточ [и др.]. - М.: Изд-во МГУ, 1978. - $208 \mathrm{c}$

4. Berggren W.A., Kent D.V., Swisher III C.C., Aubry M.-P. A Revised Cenozoic Geochronology and Chronostratigraphy // Geochronology, Time Scales and Global Stratigraphic Correlations: A Unified Temporal Framework for an Historical Geology. SEPM, Special Publications. 1995. № 54. P. 129-212.

5. Gibbard P.L., Head M.J. The newly-ratified definition of the Quaternary System/Period and redefinition of the Pleistocene Series/Epoch, and comparison of proposals advanced prior to formal ratification // Episodes. 2010. Vol. 33. No 3. P. 152-158.

6. Палеоклиматы и палеоландшафты внетропического пространства Северного полушария. Поздний плейстоцен голоцен. Атлас-монография / под ред. А.А. Величко. - М.: ГЕОС, 2009. - $120 \mathrm{c}$.

7. Строение, криогенные образования и условия формирования верхнечетвертичных отложений Надымского Приобья севера Западно-Сибирской равнины / В.С. Зыкина [и др.] // Криосфера Земли. - 2017. - Т. 21, № 6. C. 14-25. DOI: 10.21782/KZ1560-7496-2017-6(14-25).

8. Геологическое строение и генезис высоких террас Чуи и среднего течения Катуни / И.Д. Зольников [и др.] // Фундаментальные проблемы квартера: итоги изучения и основные направления дальнейших исследований. - Ростов н/Д.: Изд-во ЮНЦ РАН, 2013. - С. 226-228.

9. Зольников И.Д. Четвертичные отложения и рельеф долин Чуи и Катуни / И.Д. Зольников, А.А. Мистрюков. Новосибирск: Параллель, 2008. - 182 с.

10. Парначев С.В. Геология высоких алтайских террас (Яломано-Катунская зона) / С.В. Парначев. - Томск: Изд-во ИПФ ТПУ, 1999. - 137 с.

11. Carling P.A. Freshwater megaflood sedimentation: What can we learn about generic processes// Earth Science Reviews. 2013. Vol. 125. P. 87-113.

12. Carling P.A., Martini P., Herget J., Borodavko P., Parnachov S. Megaflood sedimentary valley fill: Altai Mountains, Siberia // Megaflooding on Earth and Mars. UK: Cambridge University Press. 2009. P. 243-266.

13. Herget J. Ice-dammed lake outburst floods in the Altai mountains, Siberia - a review with links for further readings // Tomsk State University Journal of Biology. 2012. № 1 (17). P. 148-168.

14. О скоплениях глыбового материала в долинах рек Чуя и Катунь и распространении последнего позднеплейстоценового оледенения на Горном Алтае / В.С. Зыкин [и др.] // Доклады РАH - 2016. - Т. 470, № 3. - C. 311-314. DOI: $10.7868 / \mathrm{S} 0869565216270244$

15. Новые абсолютные датировки четвертичных гляциальных паводков Алтая / А.Н. Рудой [и др.] // Известия Бийского отдела РГО. - 2006. - Вып. 26. - С. 148-151.

16. Зольников И.Д. Проблемы диагностики отложений гляциальных суперпаводков неоплейстоцена в Горном Алтае / И.Д. Зольников, Е.В. Деев // Лед и снег. - 2012. - № 3. С. $79-86$.

17. Пикард М. Критерии распознавания пород озерного происхождения / М. Пикард, Л. Хай (мл.) // Условия древнего осадконакопления и их распознавание / ред. Дж. Ригби, У. Хемблин; пер. с анг. И.П. Лаврушко, Ю.Г. Такаев. - М.: Мир, 1974. - С. 141-188.

\section{References}

1. Okishev P.A. Rel’ef i oledenenie Russkogo Altaya/ P.A. Okishev. - Tomsk: Izd-vo Tomskogo un-ta, 2011. - 382 p.

2. Zy`kin V.S. Novy`e danny`e o naibolee drevnem chetvertichnom oledenenii na Gornom Altae / V.S. Zy`kin, V.S. Zy`kina, L.G. Smolyaninova // Dokl. RAN. - 2016. - T. 466, № 3. pp. 315-318. DOI: 10.7868/S0869565216030245.

3. Razrez novejshix otlozhenij Altaya (stratigrafiya i paleontologiya Priobskogo plato, Podgornoj ravniny i Gornogo Altaya) / A.A. Svitoch [i dr.]. - M.: Izd-vo MGU, 1978. - 208 p.

4. Berggren W.A., Kent D.V., Swisher III C.C., Aubry M.-P. A Revised Cenozoic Geochronology and Chronostratigraphy // Geochronology, Time Scales and Global Stratigraphic Correlations: A Unified Temporal Framework for an Historical Geology. SEPM, Special Publications. 1995. № 54. pp. 129-212.

5. Gibbard P.L., Head M.J. The newly-ratified definition of the Quaternary System/Period and redefinition of the Pleistocene Series/Epoch, and comparison of proposals advanced prior to formal ratification // Episodes. 2010. Vol. 33. No 3. pp. 152-158.

6. Paleoklimaty' i paleolandshafty` vnetropicheskogo prostranstva Severnogo polushariya. Pozdnij plejstocen - golocen. Atlas-monografiya / pod red. A.A. Velichko. - M.: GEOS, 2009. $-120 \mathrm{p}$.

7. Stroenie, kriogenny`e obrazovaniya i usloviya formirovaniya verxnechetvertichny'x otlozhenij Nady`mskogo Priob 'ya severa Zapadno-Sibirskoj ravniny` / V.S. Zy`kina [i dr.] // Kriosfera Zemli. - 2017. - T. 21, № 6. - pp. 14-25. DOI: 10.21782/KZ1560-7496-2017-6(14-25).

8. Geologicheskoe stroenie i genezis vy`sokix terras Chui i srednego techeniya Katuni/ I.D. Zol'nikov [i dr.] // Fundamental'ny'e problemy' kvartera: itogi izucheniya i osnovny`e napravleniya dal'nejshix issledovanij. - Rostov n/D.: Izd-vo YuNCz RAN, 2013. - pp. 226-228.

9. Zol`nikov I.D. Chetvertichny`e otlozheniya i rel’ef dolin Chui i Katuni / I.D. Zol'nikov, A.A. Mistryukov. - Novosibirsk: Parallel', 2008. - $182 \mathrm{p}$.

10. Parnachev S.V. Geologiya vy`sokix altajskix terras (Yalomano-Katunskaya zona) / S.V. Parnachev. - Tomsk: Izd-vo IPF TPU, 1999. - 137 p.

11. Carling P.A. Freshwater megaflood sedimentation: What can we learn about generic processes // Earth Science Reviews. 2013. Vol. 125. pp. 87-113.

12. Carling P.A., Martini P., Herget J., Borodavko P., Parnachov S. Megaflood sedimentary valley fill: Altai Mountains, Siberia // Megaflooding on Earth and Mars. UK: Cambridge University Press. 2009. pp. 243-266.

13. Herget J. Ice-dammed lake outburst floods in the Altai mountains, Siberia - a review with links for further readings // Tomsk State University Journal of Biology. 2012. № 1 (17). pp. $148-168$.

14. O skopleniyax gly`bovogo materiala v dolinax rek Chuya i Katun ` i rasprostranenii poslednego pozdneplejstocenovogo oledeneniya na Gornom Altae / V.S. Zy'kin [i dr.] // Doklady ${ }^{`}$ RAN - 2016. - T. 470, № 3. - pp. 311-314. DOI: 10.7868/ S0869565216270244.

15. Novy`e absolyutny`e datirovki chetvertichny`x glyacial'ny`x pavodkov Altaya / A.N. Rudoj [i dr.] // Izvestiya Bijskogo otdela RGO. - 2006. - Vy`p. 26. - pp. 148-151.

16. Zol'nikov I.D. Problemy' diagnostiki otlozhenij glyacial'ny`x superpavodkov neoplejstocena v Gornom Altae / I.D. Zol nikov, E.V. Deev // Led i sneg. - 2012. - № 3. pp. 79-86.

17. Pikard M. Kriterii raspoznavaniya porod ozernogo proisxozhdeniya / M. Pikard, L. Xaj (ml.)// Usloviya drevnego osadkonakopleniya i ix raspoznavanie/ red. Dzh. Rigbi, U. Xemblin; per. s ang. I.P. Lavrushko, Yu.G. Takaev. - M.: Mir, 1974. - pp. 141-188. 